\begin{tabular}{|c|c|}
\hline $15 S N=1496-628$ & \\
\hline $\begin{array}{c}\text { TOURISM } \\
\text { AND } \\
\text { MANAGEMENT } \\
\text { AN ITTERNATONAL JOURNAL }\end{array}$ & $\begin{array}{l}\text { Journal of Tourism\&Management Research } \\
\text { ISSN: 2149-6528 } \\
2020 \text { Vol. 5, Issue.2 } \\
\text { http://ottomanjournal.com/index.html }\end{array}$ \\
\hline
\end{tabular}

\title{
A Historical Analysis on Tourism and Pandemics in the Ottoman Context: A Preliminary Research Case
}

\begin{abstract}
The purpose of this study was to examine the archieve content on the tourism regulations, the hotels and guesthouses, the tourist guiding as well as the outbreaks of pandemics and plagues in the Ottoman territories. This study was designed as a qualitative research methodology with document analysis research design. This research employed document analysis research design as it deals with existing historical records of tourism regulations in the Ottoman Empire as well as scientific data. The primary sources of data in this research are the historical archieve contents as well as secondary sources from past literature on tourism regulations in terms of accommodation, guiding, and pandemics in the Ottoman Empire. This research is expected to contribute to the literature, revealing the historical accounts. The findings show that the Ottoman Empire gave importance tourism activities, by enacting regulations on tourism and accommodation. The guiding services were also systematic, and the services were effective for the tourists. The historical data shows that the Ottomans dealt with the Black Death or later outbreaks much in the same way as the European countries, and cures which were identical to that of their northern neighbours were prescribed. The current study provides contribution to the related literature and implications for further studies.
\end{abstract}

Keywords: Ottoman, pandemics, plagues, hotel, guesthouse

Jel Classifications: $\mathrm{N}, 40, \mathrm{Z} 32, \mathrm{Z} 38$

Submitted:23/06/2020; Accepted:14/08/2020

Burak Eryilmaz, Assistant Professor. Amasya University, The Vocational School of Social Sciences, The Deparment of Tourism and Hotel Management, 05100 Amasya/Turkey

ORCID ID: 0000-0002-2179-5450

Email: burak.eryilmaz@amasya.edu.tr

\section{Introduction}

Over the last century, global tourism has been subjected to a variety of crises (Gössling et.al., 2020), including the so called 'Spanish' flu or influenza of 1918-19, the 'Asian' flu (H2N2) 
of 1957, and the'Hong Kong' flu of 1968 (Greger, 2007). Regarding more recent history, humans have witnessed 2001 Sept 11 th Terrorist Attack, 2003 SARS Outbreak, 2009 Global Economic Crisis, 2015 MERS Outbreak. Further, nowadays people across the world have been suffering from a latest novel and infectious pandemic, called coronavirus (COVID-19) which struck Wuhan, one of the most dense cities in central China in mid-December 2019 (Ghebreyesus, 2020).

This novel outbreak quickly evolved into an emerging public health issue so much so that World Health Organization (WHO) soon declared it as an unprecedented global pandemic (World Health Organization, 2020). When we consider other recent pandemics such as SARS MERS, none of them caused an longer-term lockdown as much as COVID-19, leading a serious decline in the global development of tourism (World Bank, 2020). This means that tourism activity itself can be considered as a resilient system to external shocks (Gössling et.al., 2020). However, COVID-19 has changed the rules of the game, forcing countries to impose long-term lockdowns and to restrict tourism activities, as well because it was an unexpected phenomenon for almost all people around the world despite several scenarios prepared for such outbreaks.

The pandemics that occured during the twenty-first century were due to the global change factors (Wu et al., 2017), so the challenge is now to learn as much as we can from this global tragedy (Gössling et.al., 2020). COVID-19 may make people seriously ill, even causing death, so there have been international, regional and local travel restrictions which adversely affected economics, including tourism systems, i.e. international flights or other means of transportation, day visits, cruises, etc. (Gössling et.al., 2020). Further, the precautions against COVID-19 require that sport activities which are closely related to tourism sector have been cancelled due to the pandemic, exerting to take responsibilities by the officials (Weed, 2020).

As it has been proved that infectious outbreaks such as coronavirus severely put the tourism industry in danger as it is mostly based on human mobility. For example, it has been reported that there have been almost $75 \%$ decline of occupancy in the Chinese hotel market (Baker, 2020). When we consider the population of the China and its tourism potential, this rate can be seen really worrying for the tourism activity. In this sense, tourism is considered as one of the activities that is most likely to to susceptible to any global risk factors. On the other hand, travelers' perceptions regarding the risks involved in pandemics in terms of their personal safety have a major impact on the tourism demant (Fletcher and Morakabatti, 2008).

Yang et.al., (2020) put their efforts on on evaluating the impact of coronavirus on tourism., and proposed a dynamic stochastic general equilibrium (DSGE) model to understand the effect of infectious disease outbreak on tourism. In their studies, it has been reported that since travel is likely to increase infection risk and counties impose travel bans, there is a relation between tourism consumption and health disaster risk.

The warnings of governments incited public fear, encouraging them to stay inside and to restrict outdoor activities, both of which resulted in negative outcomes for the tourism sector (McLaughlin, 2020). Some propose that there are some remedies to facilitate tourism recovery. In one of them, Yan and Zhang (2012) suggest that providing citizens tourism consumption vouchers have been useful in China following the global financial crisis and the same procedures can be followed when COVID-19 can be controlled such a level that there will be no restrictions inside and outside.

Some individuals display self-protective behaviours in the event of outbreaks, and one of the most familiar cases of consumers' self-protective behaviors in the last decades have been observed during the SARS outbreak (Chuo, 2014). Everyone, on the other hand, has no same risk perception and displays different attitudes and behaviors during the time of crises when governments don't impose lockdown. For example, in a study by Seabra et.al., (2012), travelers were classified into seven groups based on their risk perceptions: carefree (45\%), all risks concerned $(6 \%)$, satisfaction apprehensive $(9 \%)$, multiple risks concerned $(9 \%)$, health 
and personal risks concerned (11\%), terrorism and turmoil concerned (10\%) and materialists $(10 \%)$. It is seen that almost half of the travelers don't show major concerns regarding their trips. This situation has also been supported the number of the tourists who have had international flights.

Levitt (1983) asserts that tourism activity has recently been a more global sector, and thereby making it vulnareble to global crises. The price of this latest pandemic has costed much for the countries in terms of both death tolls and other related damage. One of the closest partners of the tourism sector, airlines among the sufferers of COVID-19. Some airlines have already declared lay-offs and bankruptcies (Business Insider, 2020). Several companies such as Scandinavian Airlines, Singapore Airlines, and Virgin (30 March 2020), as well as tour operators including German TUI have already requested tens of billions of US\$ in state aid (Gössling et.al., 2020).

The burden cauased by such crises as pandemics places a greater onus on tourism organisations, particularly those in the public sector with a strategic remit (e.g. National Tourism Organisations (NTO)) to take a leadership role to grasp, analyse, plan and manage crises and disasters. This is essential for both the sustainability and financial viability of a destination's tourism industry which include a wide range of tourism stakeholders which coexist in any destination (Page et.al., 2006). Literature shows that there has been a growing interest and abundant research on the significance of crises in tourism (Wilks et.al., 2005) and their impact on global tourism (Page et.al., 2006).

There have been some potential losers and winners during COVID-19. Manufacturing, financial services, education, oil and gas, construction, and real estate, automotives, aviation and maritime can be considered among the potential losers. Tourism and leisure are no exception, as well. However, agriculture, e-commerce, ICT, healthcare, food, retail and medical supply ans services are the potential winners (Consulting, 2020). There have also been revitalization efforts across the world following the outbreaks, such as Yogyakarta governments' responsive models (Hadi and Supardi, 2020).

There were also outbreaks in ancient times during the history. Among the communities who had suffered from the outbreaks were the Ottomans who had experiences plagues (Varlık, 2015), such as cholera (Welford, 2018), the Spanish Flu (Temel, 2019), the Black Death (McNeill, 1976), Smallpox, typhus, and syphilis (Ayalon, 2015), and other several outbreaks (Panzac, 1985).

The primary focus of historians of the Ottoman Empire mostly has been the political, economical, cuisine, and architecture, but a few have delved into such subjects as natural disasters and plague epidemics when compared to researchers from Europe and China (Ayalon, 2015). By close analyzing the tourism activities occuring in the Ottoman territories, particularly with the entrepreneurship of Thomas Cook (Towner, 1995), the Ottoman Empire encompasses significant historical data to figure out what were the past phenomenon and drawing some conclusions for the future.

This research is about the tourism regulations during the Ottoman Empire. On the other hand, there is limited research on guiding and interpreting as well as plagues during the Ottoman Empire. From this perspective, it can be noted that this is a gap in the literature that needs to be filled with new inquiries. In terms of daily routines during the Ottoman Empire, it would be useful to focus on tourism regulations such as accommodation, guiding, and dealing with outbreaks to provide new insights into understanding is expected to contribute to the literature, revealing the historical accounts. The main consideration of this research was to examine the archieve content on the tourism regulations, hotels and guesthouses, tourist guiding and interpretation as well as outbreaks of pandemics and epidemics. The following research questions framed the study:

1. What were the laws and legislative regulations on hotels and guesthouses as well as tourist guiding? 
2. What were the Ottomans' experience with plagues, epidemics, and pandemics and their preventions?

\section{Literature Review}

The Ottoman Empire reigned across a vast territory and lasted long for more than six centuries (Ayalon, 2015; Brummett, 2009). The Ottomans in İstanbul lived on a junction point between The East and the West cultures. Despite the long time after the fall of the Ottoman, one can see the traces of the past in a number of historical, cultural, and religious attractions as the Anatolian territories hosted diverse civilizations (MacLean, 2006). Having been expanded during the early periods of 14th century $\mathrm{AD}$, the Ottomans was a great power controlling from southwestern Asia to northern Africa with a diverse population with different ethnic, religious, social and political groups (Farooqhi, 2017).

An examination of literature has shown that there have been studies on the historical development of the tourism and the hotels built in those periods, and these were mostly conducted by the researchers from the departments of history. These studies are as follows: "A Facilitated Access Model and Ottoman Empire Tourism" (Nance, 2007), "The Ottoman Empire's First Attempt to Establish Hotels in İstanbul: The Ottoman Imperial Hotels Company" (Arslan and Polat, 2015), "A Hotel in Anatolia in the Last Period of the Ottoman Empire: Hotel Tadia (1892-1922) (Y1lmaz et.al., 2018), "Guidance Services and Legal Regulations Aimed at Interpreters and Guides during the Ottoman Empire" in the 19th century (Arslan and Polat, 2016), "Regulations about the Guest Houses and the Hotels in the second half of 19th Century of Ottoman Empire" (Çetin, 2018).

Since 1830s, guide books had been started to be published to help those who wished to travel to the Ottoman territories from Europe. Booklets and guide books published for travellers were significant indicators of the fact that the Ottoman Territories, particularly İstanbul, were one of the most popular destinations of the Europeans. Such publishings as booklets related to the Ottoman Empire in England, the United States of America and France included practical information, recommendations and warnings for tourists (İnal, 2014).

Previous research has revealed that the Ottomans suffered from a variety of pandemics and epidemics which were the most documented calamity affecting the Ottomans (Ayalon, 2015) as well as plague (Varlık, 2015), such as cholera (Welford, 2018), the Spanish Flu (Temel, 2019), the Black Death (McNeill, 1976), Smallpox, typhus, and syphilis (Ayalon, 2015), and other several outbreaks (Panzac, 1985). The Ottomans, on the other hand, implemented some practices in terms of the measures and treatments (Erer and Erdemir, 2010; Shefer-Mossensohn, 2009), including such quarantine (Arslan and Polat, 2017) and filiation (Demirtaş and Tekiner, 2020). The literature has revealed that "Medicine and Power in Tunisia, 1780-1900" is one of the preliminary work concerning the epidemics in an Ottoman context by Gallagher (1983). Then, Panzac (1985) documented the plague in the Ottomans in the work "La peste dans l'empire Ottoman: 1700-1850". There is also Turkish scholars who has deeply focused on the plague during the Ottoman period: Varlık (2015) with "Plague and Empire in the Early Modern Mediterranean World: The Ottoman Experience, 1347-1600" and Bulmuş (2012) "Plague, Quarantines and Geopolitics in the Ottoman Empire".

\section{Methodology}

In this present study, the document analysis research design was adopted. This research employed document analysis research design as it deals with existing historical records of tourism regulations in the Ottoman Empire as well as scientific data. According to Botterill and Platenkamp (2012), interest in document analysis among tourism researchers has largely expanded as in social science since the 1950s. Document analysis research is a popular 
research desing particularly for the archival documents (Bowen, 2009; Cheia, 2010). It is a systematic procedure for reviewing and evaluating documents and requires researchers to interpret data to reveal the meaning (Corbin and Strauss, 2008).

The primary sources of data in this research are the historical archieve contents as well as past literature on tourism regulations in terms of accommodation, guiding, and pandemics in the Ottoman Empire. Past documents generally are the form of primary evidence, so they can be invaluable to a qualitative study (Yin, 2016). In this context, archives are one of the oldest and most used sources of data for researchers who rely on written texts and visual images to piece together histories of salient events. Further, they are best known for their importance in historical research, tourism (Timothy, 2012). In this sense, the detailed examination of historical archive documents (Jupp, 2006) has been carried out in this study.

The researcher's role is to select which information to use and how to analyse it. In this sense, the historical archive of the Ottoman Empire was examined. The data collection steps were (1) access to the data, (2) checking the authenticity, (3) comprehensibility of the data, (4) analyzing, and (5) employing the obtained data. For the obtaining data, the official permission was obtained from the Directorate General of State Archives in Turkey. Researchers must have an elaborate and accurate simplification, transliteration and translation of the Ottoman chronicles and archival documents. In this sense, for the avoiding misinterpretation, the assistance of a a language expert and a history expert were consulted.

Despite the richness in the archieve contents, researchers critically need to evaluate the documents. The documents shouldn't be considered as the exact recordings of the events or the phenomena (Bowen, 2009). Paying attention to the trustworthiness issue is essential for making the tourism research rigorous (Decrop, 2004). In this research, the typology mentioned by Lincoln and Guba (1985) was adopted to ensure trustwortiness. In this sense, four criterias were suggested as credibility, transferibility, dependability, and confirmability. In terms of credibility, the data is based on the archieve content and literature. Given the transferability, the historical data is stable despite the interpretation from the perspective of the researcher. In this study, the details about the context of the study in terms of the data collection process were explained. For the dependability, our results are in line with the previous literature on tourism regulations cited in this paper. When it comes to confirmability, the author didn't manipulate any source of data. In this sense, the data analysis process was conducted in an objective way.

\section{Results}

\subsection{Regulations on Hotels and Guesthouses}

Hotels can be considered as one of the most prominent and basic expressions of the tourism industry in any given country or settlement. This is mostly because their physical properties can be observed from tje outside. On the other hand, there is little research on the hotels or other acommodations (Shoval and Cohen-Hattab, 2001). Accommodation system was affected by the modernization period of the Ottoman Empire during the 19th century. Such buildings as caravanseria and inns were started to be replaced with modern hotels and guesthouses that are suitable for European lifestyles in the Ottoman cities. The hotels in this period, which seemed to be equipped with the advanced technologies, were among the first buildings which had lightning via electricity, generator power unit, elevator and central heating system (Çelebi, 2011).

The Hotel d'Angleterre, built in Pera by James Misserie in 1841, is accepted as the first hotel built during the Ottoman Period (Arslan and Polat, 2015). The information included in the tourist guide books during that period seems to support the fact that the Hotel d'Angleterre bear similarities with the ones in Europe (Gülersoy, 1985). Apart from this hotel, Pera Palas, Tokatliyan Hotel, Grand Hotel d'Orient, Hotel de Bysance, Hotel de Londre, Grand Hotel de Luxembourg, Hotel de Paris can also be regarded as prominent figures of 
their own periods (Deleon, 1993). As the touristic activities developed in Anatolia, such hotels as the Hotel Tadia started to host guests (Y1lmaz et.al., 2018).

Arslan and Polat (2015), on the other hand, argued that there was a considerable increase in the number of tourists who visited the Anatolia, particularly İstanbul, from the European countries in the 19th century, but the accommodation wasn't good enough to host the individuals visiting the country. The authors dwelled on "the Ottoman Imperial Hotels Company" to inform the readers about the regulations to satisfy the accommodation need in line with the number of the visitors of İstanbul. Yilmaz et.al., (2018) mentioned that the city was revived through the Berlin-Baghdad Train Route in the city of Eskişehir, which was undeveloped during the last quarter of the 19th century. The passengers began to spend the night in the city, and therefore, there needed more hotel capacity to meet the demand. The authors concluded that the Hotel Tadia, built by Madame Tadia to be able to meet the demand, made significant contributions to the tourism history of the city. When it comes to the tourist guides during the Ottoman Empire period, Arslan and Polat (2016) argued that the Ottoman Empire attached great importance to the tourist guiding at the turn of the nineteenth century and designed a professional system for tourist guides by means of some certain legislations in 1890. Çetin (2018) investigated the regulations on the hotels and the guesthouses during the last period of the Ottoman Empire and focused on the locations and legislative regulations on government buildings, as well as the obstacles and applications.

The first legislation related to the accommodation in İstanbul and its environments during the Ottoman Period was the regulation 'Legislative Regulations on Hotels and Guesthouses in Dersaadet and Bilad-1 Selase', including eleven items, prepared by Mösyö Bunt who was a police counsellor in 1887. Within the scope of this regulation, those who wanted to run a hotel were obliged to inform the police department first, and then put plates including the hotels name to make them known for public. They were also required to write down the names, professions, entrance date, accommodation dates of the guests in an official notebook. Even after a period of time, the hotel owners were written down this demographic information both Turkish and French languages. This first practice also laid the foundation of the future regulations related to accommodation. After all, a new regulation that included 9 items on the opening and operating of the hotels as well as services provided in these buildings was issued (Çetin, 2018).

Following the Sergi-i Umumi-i Osmani, issued in 1863, which paved the way for the development of tourism activities during the Ottoman period, the hotel and accommodation services were included in the city planning. For example, the sites for building hotels were determined as Pera, Büyükdere, Üsküdar and Büyükada regions through the İrade-i Seniyye issued in 1865 (Yakartepe and Binan, 2011). In this regard, it can be noted that this practice may have impacted the concentration of the hotels in these regions as much as being popular areas of İstanbul.

The letter sent by the person whose name was Ernest Erman was an attempt to develop tourism in the Ottoman territories from Munich in May 1916. In the letter, the main focus was to attract the German tourists to the natural beauties of the Ottoman territories, and direct those tourists visiting such countries as Sweden and Italy to the Ottoman region. This letter was welcomed by Trade and Agriculture Institution in the Ottoman State (Yüksel, 2010). In order to prevent the adverse conditions or events in the recreational centers in İstanbul, it was decided to keep the official records of the demographic characteristics of the owners of the buildings (DOA. I.HUS. 88/49). Topuz (2017) mention that these preventions by the state may have derived from the economical and political concerns of the Ottoman officials. Regarding the hotel industry, the state began supporting financially and supervising the buildings who had taken the official permissions. In this sense, a hotel named "Tarabya Palas" had been confirmed to be built, but following the supervisions, it was found that the company built a club instead of a hotel, so the permission was cancelled (DOA. İ.HUS. 25/80). In line 
with those developments, there were some regulations on the hamams in terms of health and recreational areas. Additionally, the transportation was tried to be improved. In this sense, they forned a commission and took the decisions below:

- A city plan would be prepared so that the structure of the city didn't change later on.

- A revision would be made on the streets and huge buildings as well as water resources.

- For making İstanbul, the recommendations by the Ernest Ermen would be paid attention.

- A zoo would be built in a convenient area of the city (Yüksel, 2010).

\subsection{Regulations on Tourist Guiding and Translators}

In order to promote and raise awareness about tourism in a country, the tourist guides play a significant role. Additionally, they can help the visitors leave the country with good experiences, thereby causing them to come back again. The tourist guides can be considered as omniscient ambassadors in that they must have the accurate information about the attractions about which they talk. Therefore, the special trainings are required to transmit the information in an effective way (Yenipınar and Çapar, 2017). There is evidence to suggest that tourist guiding practice dates to the Ottoman period. Based on the court records in 1640s, the Muslim tourists who visited the holy places such as Jerusalem, Qubbat As-Sakhrah and Al-Aqsa Mosque were accompanied by a team of tourist guides (dallun) with ten members. On the other hand, the unauthorised tourist guiding problem occured during the Ottoman Period as it is today, and this situation was complained to the Qadi, the muslim judge. Additionally, the Christian and the Muslim tourists visiting the Jerusalem would have to be accompanied by their own co-religionists (Cohen, 2001). In this sense, it can be noted that speaking the same language and visiting the holy places must have affected the selection of tourist guides.

Towards the 19th century, there was a significant increase in the number of travellers and tourists visiting the Ottoman territories thanks to advances in transportation. The tour operators started to establish a network for the Ottoman territories, particularly İstanbul through meetings with the Ottoman authorities (Yüksel, 2010). At this precise point, the guiding and translation services were needed to meet some standards. In this sense, the tourist guides were made to obtain the document "şehadetname", means authority for the guides in accordance with the legislation 'Seyyahine Tercümanlık Edenler Hakkında Nizamname' issued on 10th November 1890 (Arslan and Polat, 2016). According to the first article of this regulation, the tourist guides who wanted to give service to the tourists visiting the Ottoman territories and those who had hotels or guesthouses and would guide in their regions were obliged to obtain an official document. The second article, on the other hand, stated that those who wanted to be authorised shouldn't have been previously convicted by any crime or murder. The tourist guides were required to take an official document from the mukhtar and submit it to the local municipalities in their region 64 (Düstur, 1/6, p. 784-785).

The tourist guides whose documents were confirmed were obliged to enter an exam. The exam would test the candidates' Turkish and foreign language proficiencies as well as knowledge levels on tourist attractions. Those who would be successful with the exam was able to get the document 'şehadetname'. Furthermore, the tourist guides had to give their official permissions "şehadetname" when they were accused of giving harm to the tourist and were found guilty (Düstur, 1/6, p. 784-785).

When we examine the articles of this regulation, it can be noted that the foundations of the current legislative regulations on the tourist guiding were laid down during those times. Said another way, the tourist guides today have to obtain an official permission so that they can give service in accordance with the 'Tourist Guiding Professional Law' with the reference 
number 6326 dated in 2012 and "Tourist Guiding Professional Instructions" dated in 2014, based on the former legislation. They also need to submit that they haven't been convicted of any crime, have proficiency in foreign language skills. They have to enter the exam that tests the knowledge of the tourist guides on the attractions successfully.

Based on the evidence, it can be suggested that it may have been targeted that the individuals who wanted to be tourist guides could be controlled through 'Seyyahine Tercümanlık Edenler Hakkında Nizamname', enacted in the modernization period of the Ottoman Empire. The authorities may have attemped to protect the reputation of the state, stating that those who had been convicted of any crime couldn't work as tourist guides. These actions of the Ottoman authorities can be considered as preventive measures in terms of both the state and the tourism. Aune (2003) emphasizes that foreign diplomats and merchants in the Ottoman Empire were able to recruit Janissaries for such services as protection, guidance, and interpreting. The Ottoman officials gave their efforts to ensure that the regulation being in force would be practiced, while they were investigating the legislations of the western countries to improve the system (DOA, DH. EUM. MKT, 80/53). Despite these efforts, there were lots of unauthorised guides around the touristic areas of İstanbul as it is today. The case mentioned below was an example of this in the archive content (DOA, ZB, 336/139):

"Two Ottoman citizens, named as Yanko and Nikola were contniously guiding the tourists around the Hagia Sophia despite not being authorised by the officials. However, they complained to the Evkaf-ı Hümayun Nezaret about the janitors as they weren't allowed to enter the Hagia Sophia. The Evkaf-ı Hümayun Nezareti inquired into the event. Tje janitors admitted that they didn't allow Yanko and Nikola to enter the building as they had been ordered to put the legislation into the practice. Istanbul Police Department informed that they hadn't been authorised tourist guides, couldn't submit their official permissions, forced the tourists to enter the Hagia Sophia, would ignore the praying times, and threatened the officers there. As a matter of fact, Yanko and Nikola obtained their official documents following the legislation of the tourist guiding. After submitting their documents, they were allowed to enter the Hagia Sophia except the praying times".

In addition to the fighting against the unauthorised tourist guiding, another significant issue which had to be dealt with by the Ottoman authorities was to employ tourist guides who would hold the belief that The Turks have a civilised nation and would not conspire against the Ottoman Empire. For this purpose, 'Müstakbilin (Meeting) Committee' was established in 1922. According to this committee, the efforts were given to inform the foreigners on the Turks and Turkish civilisation and prevent the non-Muslim tourist guides from misinforming the tourists about Islam, Turkishness and Turkish people.

Prior to the Turkish Republic period, the first regulations on guiding services were based on the Nizamname, issued with 190 reference number in 1890. Those times, the translation and interpretation services were provided by the Jewish people who consisted of the most of the minorities. Those people whose origins traced back to France, Italian, and Malta had no education but just knew foreign languages. They were interpreting tourists who visited the Ottoman Territories. So much so that, In a book with two volumes by Amicis (1896) on İstanbul, it was clearly stated that:

"...Saddled horses stand waiting for you in every square; boats with their sails spread are ready to take you anywhere you may choose to go; steamboats lie at every pier awaiting nothing but the signal to depart; kâiks manned with rowers and skiffs fitted with sails crowd the 
landing-places; while an army guides, speaking every language of Europe, is at your disposal for as long a time as you may want any of them...".

\subsection{Pandemics, Epidemics and Plague During the Ottoman Empire}

This part of the study delves into the pandemics, epidemics, and plagues during the Ottoman Empire based on the archieves and previous research and drawing some conclusions as to what effects occured due to these outbreaks and how the Ottoman Empire authorities dealt with them.

A review of previous research has revealed that the Ottomans suffered from a variety of pandemics and epidemics which were the most documented calamity affecting the Ottomans (Ayalon, 2015) as well as plague (Varlık, 2015), such as cholera (Welford, 2018), the Spanish Flu (Temel, 2019), the Black Death (McNeil, 1976), Smallpox, typhus, and syphilis (Ayalon, 2015), and other several outbreaks (Panzac, 1985). The Ottomans, on the other hand, implemented some practices in terms of the measures and treatments (Erer and Erdemir, 2010; Shefer-Mossensohn, 2010), including such quarantine (Arslan and Polat, 2017) and filiation (Demirtaş and Tekiner, 2020). The literature review has revealed that "Medicine and Power in Tunisia, 1780-1900" is one of the preliminary work concerning the epidemics in an Ottoman context by Gallagher (1983). Then, Panzac (1985) documented the plague in the Ottomans in the work "La peste dans l'empire Ottoman: 1700-1850". There is also Turkish scholars who has deeply focused on the plague during the Ottoman period: Varlık (2015) with "Plague and Empire in the Early Modern Mediterranean World: The Ottoman Experience, 1347-1600" and Bulmuş (2012) "Plague, Quarantines and Geopolitıcs in the Ottoman Empire".

Plague is defined by Varlik (2015) as a zoonosis (animal-to-human disease) that basically impacts rodents, but humans are also vulnerable to this even if it is only accidental hosts to it. This condition has a complex etiology that encompasses the rodents, human populations, and the environment (Varlık, 2015). Plagues often caused the fatalities in a very short time during the Ottomans. Until the second half of the 19th century, plague was endemic in İstanbul. Called "veba" in Turkish, the plague was known as "bubonic plague", known as "Black Death" in the West was the cause of the death (Panzac, 1985). Temel (2019) has concluded that no historical documentation that is about the flu epidemics in İstanbul in the years of before 1918 in spite of the fact that the extensive and smallpox data were documented.

In broad terms, quarantine (lockdown) is said to be one of the oldest measure taken by authorities along with other social distancing measures aimed at excluding individuals with infectious from daily life, and this measure has been used for centuries as home, work, travelers, institutional, and cordon sanitaire. It was revealed that plague epidemics mostly transmitted by sea from the harbor area at İstanbul to the Balkans, Black Sea region, and Alexandria in Egypt (Panzac, 1985). It was found that there were marine trips from several countries, including England and France to and from Athens and Istanbul. Therefore, Syra, one of the Cyclades of Greece, was an area where the goods were transhipped and the passengers were quarantined (Arslan and Polat, 2017).

When it comes to preventive measures of the Ottomans, the officials took important steps in the science and medicine so much so that from the 19th century, the officials in the Ottoman state focused their efforts to adopt effective European quarantine practices. One of them was during the cholera epidemic of 1831. The quarantine was enforced on ships sailing from the Black Sea to İstanbul. Another one, which was a more systematic practice was implemented in Çanakkale in 1835 to prevent cholera threat from the Mediterranean region (Arslan and Polat, 2017). There is also evidence that during the 1830s, there were protests by the Europeans, particularly British and French in that the quarantine implementation by the Ottoman in 1830s was contrary to the Ottomans to free trade since they considered the 
lockdown as cruel and unnecessary measures, but later on they understood the importance of this, as well (Bulmus, 2012).

The epidemic phase of plague, on the other hand, didn't last for longer periods even without any attempt to control or treat the disease due to the moderate climate in the Ottoman areas. In this sense, for example, plague normally begin in April or May, reach the hightest levels in Augusut and September, and recede in November and December (Varlik, 2015). In addition to quarantine, another practice conducted by the Ottomans was filiation mentioned in the newspapers published in French in July 1857 in "Gazette Médicale d'Orient". The filiation practices at times were primarily practiced by some European physicians in the country (Demirtaş and Tekiner, 2020). Figure 1 illustrates the news on the practices.

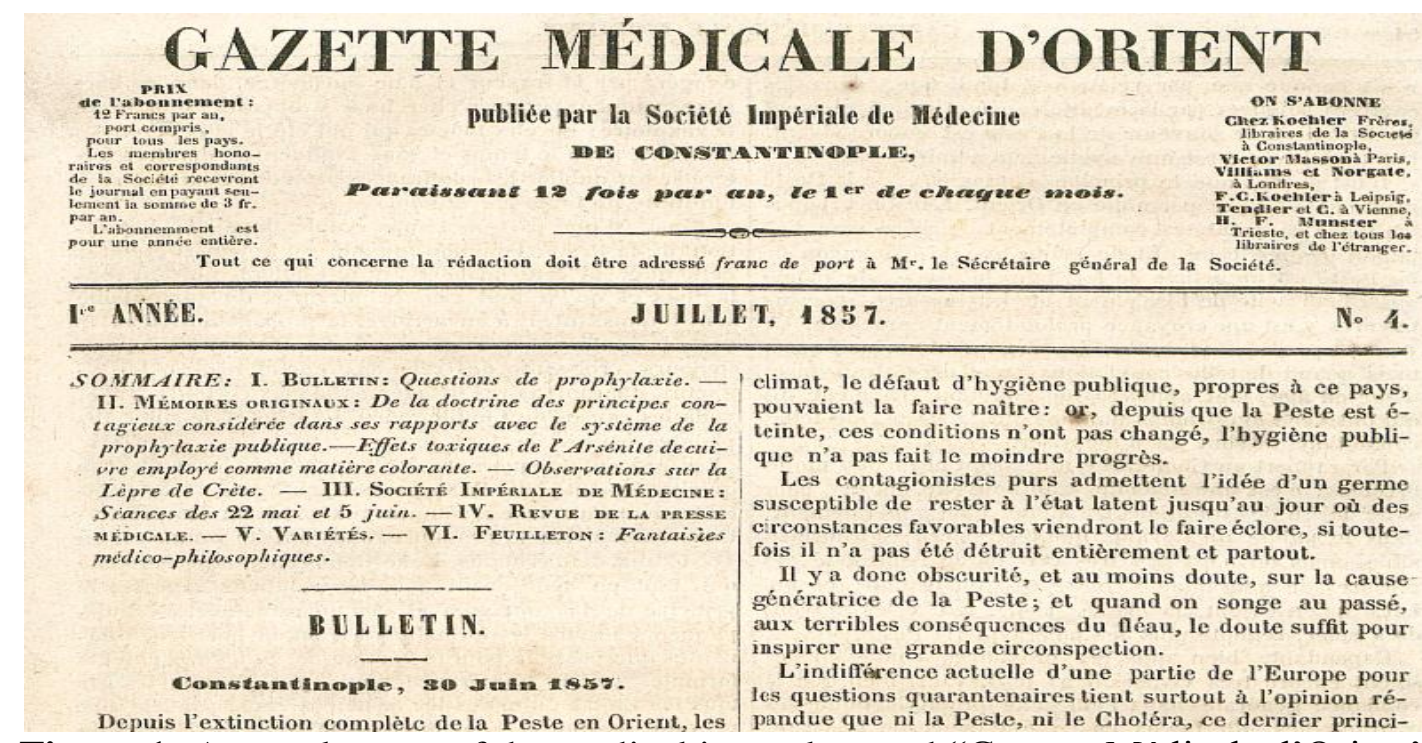

Figure 1: A sample page of the medical journal named "Gazette Médicale d'Orient" during the Ottoman.

\section{Conclusion, Implications and Limitations}

The current research study has sought to reveal the tourism regulations in general, on hotels and guesthouses, guiding and interpreting services, as well as plagues during the Ottoman Empire. Determining the locations of the hotels, the requirement of submitting the identity, and the obligation of having tourist guiding certificate to work as a tourist guide are the most common ones. Moreover, there were similarities between the old times and today in terms of the problems faced. For example, tourist guides without certificates existed during those days as it is now. The Ottoman Empire felt the necessity to take some precautions against the threats directed by foreign visitors, especially outside the country and put into practice a wide range of practices. The administrators who were aware of the fact that other states might take the advantage of any rebellion, so they attached great importance to these issues. Not allowing the visitors to enter the country without any permission, identification of the guides and translators against the country and prevention them from behaving in a way that would harm the reputation of the country, as well as permitting them to work with the examination and authorization certificate are good indicators of this awareness. Along with the increase in the number of tourists visiting the Ottoman territories, the nineteenth century became the period in which legislative regulations on tourism were boosted. The system established during this period can be asserted to shed light on the current practices.

Previous literature on the historical developments of tourism in Turkey mostly refers to the post Turkish Republic period. Little research has focused on the tourism regulations during the Ottoman Empire, and researchers from departments of history often examined the regulations in terms of security and travellings to the Ottoman territories rather than tourism 
centered approach. The tourism developments across the world have boosted following the Second World War. Regarding this, Yüksel (2010) notes that the biggest challenges for the Ottomans in terms of the regulations and innovations were the inconvenient conditions and period particularly due to several wars. If there hadn't been the fall of the Ottomans due to the conflicts and wars, the tourism today would be at a different status.

When we examine the regulations for the tourism by the Ottomans, it is seen that there are similarities on the regulations between today and past. In other words, it can be argued that most of the regulations in tourism today may have been rooted during the Ottoman Empire. For example, determining the locations of the hotels, the necessity of informing on the identity, and requiring certificates for tourist guiding are the most outstanding ones. Even, such problems as tourist guides without certifications were one of the most common issues those days as it is in today.

Based on the statistics of Ministry of Culture and Tourism, Germany is second to Russia among the countries whose citizens visit Turkey as tourists with five million entrances in 2019 (Ministry of Culture and Tourism, 2020). As stated by Yüksel (2012), the interests of Germans to the Anatolia dates back to the Ottoman Empire period. As it is today, the Ottoman officials attempted to take precautions for German tourists to be able to travel without any obstacle.

Enforcing those who wanted to enter the territories of the Ottomans to take an official permission, what is visa today, noting the personal information of those staying in the hotels, and allowing guides and interpreters to work based on the several requirements and examinations so as to prevent people with bad intentions from acting inconveniently, particularly for the state are very similar actions today.

The attitude of the Ottoman state towards plagues and pandemics is another similarity with today. In this sense, the Ottoman Empire gave importance to such illnesses as cholera and Black Death, and made visitors stay under quarantine. Lockdown and travel restrictions are common practices of the Ottomans. Quarantine centers, called as "Tahaffuzhane", were the places where those who entered or exited the any area in the Empire were kept under quarantine to prevent the plagues or pandemics from spreading. Those with symptoms were also treated in Tahaffuzhane (Sariyıldiz, 1996). Despite different practices then, the quarantine periods were mostly two weeks period in the Ottomans (Arslan and Polat, 2017). It is seen that the 14 days quarantine implementation, with which most people have become familiar today was one of the most premilinary practices of the Ottomans during 1800s.

While making decisions or plans for the future, it is important to refer to the past practices, particularly decisions for tourism concept that address millions of people across the world. In this qualitative study, the practices of the Ottomans on tourism, hotels and guesthouses as well as pandemics and plagues. There are very important similarities in terms of practices and problems, as well. This may be caused from the cultural roots in the same territoty. Despite the changes and developments occuring today when compared to the Ottoman period, it would be useful to delve deeply into the archieves and reveal the practices of the Ottomans, particularly services for the community, economic, education, health etc. This can navigate authorities today to implement good practices and to avoid the ineffective ones.

Research based on the archieves has been conducted for centuries, and this trend will likely to continue in the historical research for centuries to come (Timothy, 2012). This study has several limitations. The first drawback stems from conducting a research based on the archieve content as the secondary data sources are less flexible in that researchers cannot ask the questions they want. In other words, one who want to delve into the historical accounts in the distant past has to refer to archival content. Another limitation is that the subjectivity issue. Depictions of past accounts were interpreted from the researchers perspective despite attempts to be committed to scientific cycles. This is called as "selective deposit" by Timothy 
(2012). A similar issue mentioned by Keppel et.al., (1992) is "selective survival", which refers to the limited number of archieved contents for the analysis. Finally, given the Ottoman Empire reigned across vast territories, there were many different languages used in the borders of the empire. Therefore, this study is based on the archieves in the Ottoman language and previous literarute in Turkish and English. There may be other historical data or literature on different languages. This can be considered as a limitation.

For the future research, scholars can focus on archieves on different languages to be able to collect more detailed data. Further, there may be meta-analysis studies to design a frame for the tourism research during the Ottoman Empire. Researchers also conduct research in nearby countries and compare the results with the current study. Further, this study can be seen a short account of the subtitles with its findings. In the future, each of the subtopics can be delved into in detail separately and a more detailed archival content may be unearthed.

\section{References}

Amicis, E. D. (1896). Constantinople. Philadelphia : Henry T. Coates \& Co.

Arslan, A., and Polat, H. A. (2015). The Ottoman Empire's first attempt to establish hotels in İstanbul: The Ottoman imperial hotels company. Tourism Management, 51, 103-111.

Arslan, A., and Polat, H. A. (2016). Guidance services and legal regulations aimed at interpreters and guides in the 19th century Ottoman Empire. Tourism Management Perspectives, 19, 40-47.

Arslan, A., and Polat, H. A. (2017). Travel from Europe to Istanbul in the 19th century and the Quarantine of Çanakkale. Journal of Transport \& Health, 4, 10-17.

Aune, M. (2003). An Englishman on an elephant: Thomas Coryate, travel writing and literary culture in early modern England (Unpublished Doctoral Dissertation). Wayne State University, Michigan.

Ayalon, Y. (2015). Natural Disasters in the Ottoman Empire. Cambridge: Cambridge University Press.

Baker, T. (2020). Chinese hotels seeing steep declines from coronavirus. http://hotelnewsnow.com/Articles/300132/Chinese-hotels-seeing-steepdeclines-from coronavirus. Accessed 01.August 2020.

Botterill, D., and Platenkamp, V. (2012). Key concepts in tourism research. Tousand Oaks: Sage Publishing.

Bowen, G. A. (2009). Document analysis as a qualitative research method. Qualitative research Journal, 9 (2), 27.

Brummett, P. (2009). Mapping the Ottomans. Cambridge: Cambridge University Press.

Bulmuş, B. (2012). Plague, Quarantines and Geopolitics in the Ottoman Empire. Edinburgh: Edinburgh University Press.

Business Insider. (2020). UK airline Flybe declares bankruptcy as coronavirus dooms the already struggling carrier. https://www.businessinsider.de/international/uk-airlineflybe-declaresbankruptcyflights-grounded-2020-3/?r=US\&IR=T. Accessed 02 August 2020.

Cheia, G. (2010). Research methods in tourism. GEOREVIEW: Scientific Annals of Stefan cel Mare University of Suceava. Geography Series, 19(2), 81-94.

Chuo, H. Y. (2014). Restaurant diners' self-protective behavior in response to an epidemic crisis. International Journal of Hospitality Management, 38, 74-83.

Cohen, C.B. (2001). Island is a woman: women as producers and products in British Virgin Islands Tourism. In Y. Apostolopoulos, S. Sonmez \& D.J. Timothy (Eds.), Women as Producers and Consumers of Tourism in Developing Regions (pp. 47-72), Westport: CT: Praeger. 
Consulting, D. E. and F. (2020). Advice is judged by results, not intentions. Dcode Economic \& Financial Consulting. https://dcodeefc.com/corona.jogjaprov.go.id. Accessed 01. August 2020.

Corbin, J. and Strauss, A. (2008). Basics of qualitative research: Techniques and procedures for developing grounded theory. London: Sage Publishing.

Çelebi, M. E. (2011). Galata ve Pera'da otel yapılarının gelişimi (1840-1914). Sigma, 3, 300307.

Çetin, E. (2018). 19. Yüzyılın İkinci Yarısında Osmanlı Devleti’nde Otel ve Misafirhanelere Dair Düzenlemeler. Anatolia: Turizm Araştırmaları Dergisi, 29 (1), 63-76.

Decrop, A. (2004). Trustworthiness in qualitative tourism research. Qualitative Research in Tourism: Ontologies, Epistemologies and Methodologies, 156-169.

Deleon, J. (1993). Bir tutam İstanbul. İstanbul:Altın Kitaplar Yayınevi.

Demirtaş, T., and Tekiner, H. (2020). Filiation: A Historical Term the COVID-19 Outbreak Recalled in Turkey. Erciyes Medicine, 42.

DOA, İ. HUS, 88/49. (The Directorate of Republican Archives and the Directorate of Documentation, The Directorate of Ottoman Archives).

DOA, I.HUS, 25/80 (The Directorate of Republican Archives and the Directorate of Documentation, The Directorate of Ottoman Archives).

DOA, DH. EUM. MKT, 80/53 (The Directorate of Republican Archives and the Directorate of Documentation, The Directorate of Ottoman Archives).

DOA. ZB. 336/139 (The Directorate of Republican Archives and the Directorate of Documentation, The Directorate of Ottoman Archives).

Düstur, 1/6, Ankara 1939, pp. 784-785.

Erer, S., and Erdemir, A. D. (2010). Preventive measures and treatments for cholera in the 19th century in Ottoman archive documents. Vesalius: Acta Internationales Historiae Medicinae, 16 (1), 41-48.

Farooqi, N. R. (2017). An Overview of Ottoman Archival Documents and Their Relevance for Medieval Indian History. The Medieval History Journal, 20 (1), 192-229.

Fletcher, J., and Morakabati, Y. (2008). Tourism activity, terrorism and political instability within the commonwealth: the cases of Fiji and Kenya. International Journal of Tourism Research, 10 (6), 537-556.

Gallagher, N. E. (1983). Medicine and Power in Tunisia, 1780-1900. Cambridge: Cambridge University Press.

Ghebreyesus, T. A. (2020). WHO Director-General's opening remarks at the media briefing on COVID-19 (11 March 2020). https://www.who.int/dg/speeches/detail/whodirectorgeneral-s-opening-remarks-at-the-media-briefing-on-covid-19-11-march-2020. Accesed 29 July 2020.

Gössling, S., Scott, D., and Hall, C. M. (2020). Pandemics, tourism and global change: A rapid assessment of COVID-19. Journal of Sustainable Tourism, 1-20.

Greger, M. (2007). The human/animal interface: Emergence and resurgence of zoonotic infectious diseases. Critical Reviews in Microbiology, 33(4), 243-299.

Gülersoy, Ç. (1985). Hotel d'Angleterre. İstanbul: Türkiye Turing ve Otomobil Kurumu Yayını.

Hadi, S., and Supardi, S. (2020). Revitalization Strategy for Small and Medium Enterprises after Corona Virus Disease Pandemic (Covid-19) in Yogyakarta. Journal of Xi'an University of Architecture \& Technology, 12(4), 40-68.

İnal, H. İ. (2014). Osmanlı Imparatorluğu Tarihi. İstanbul: Nokta Kitap Yayınları.

Jupp, V. (2006). The Sage dictionary of social research methods. London: Sage Publishing.

Keppel, G., W.H. Saufley and Tokunaga, H. (1992). Introduction to Design and Analysis: A Student's Handbook, New York: W.H. Freeman and Company.

Levitt, T. (1983). The globalization of marketing. Harvard Business Review, 7,92-102.

ORIGINAL SCIENTIFIC PAPER

Eryilmaz, B.

2020, Vol.5, No.2, pp.681-695. DOl:10.26465/ojtmr.2018339536 
Lincoln, Y.S., and Guba, E.G. (1985). Naturalistic inquiry. Newbury Park, CA: Sage

McLaughlin, T. (2020). Coronavirus is devastating Chinese tourism. https://www.theatlantic.com/international/archive/2020/02/economycoronavirusmyanmar-china-tourism/606715/. Accessed 01 August 2020.

MacLean, G. (2006). Writing Turkey: Explorations in Turkish history, politics, and cultural identity. London: Middlesex University Press.

McNeill, W.H. (1976). Plagues and Peoples. New York: Doubleday.

Ministry of Culture and Tourism (2020), 2019 General Tourism Statistics, Retrieved from https://yigm.ktb.gov.tr/Eklenti/69320,turizmistatistikleri2019-4pdf.pdf?0. Accessed 10 February 2020.

Nance, S. (2007). A facilitated access model and Ottoman Empire tourism. Annals of Tourism Research, 34(4), 1056-1077.

Page, S., Yeoman, I., Munro, C., Connell, J., and Walker, L. (2006). A case study of best practice-Visit Scotland's prepared response to an influenza pandemic. Tourism Management, 27(3), 361-393.

Panzac, D. (1985). La peste dans l'Empire ottoman, 1700-1850. Leuven.

Sarıyıldız, G. (1996). Hicaz Karantina Teşkilatı (1865-1914). Türk Tarih Kurumu Yayınları, Ankara.

Seabra, C., Dolnicar, S., Abrantes, J. L., and Kastenholz, E. (2013). Heterogeneity in risk and safety perceptions of international tourists. Tourism Management, 36, 502-510.

Shefer-Mossensohn, M. (2009). Ottoman Medicine: Healing and Medical Institutions, 1500 1700. New York: Suny Press.

Shoval, N. and Cohen-Hattab, K. (2001). Urban hotel development patterns in the face of political shifts. Annals of Tourism Research, 28(4), 908-925.

Temel, M. K. (2019). The 1918 "Spanish Flu" Pandemic in the Ottoman Capital, Istanbul. Canadian Bulletin of Medical History, 37(1), 195-231.

Timothy, D. J. (2012). Archival Research. In L. Dwyer, A. Gill \& N. Seetaram (Eds.), Handbook of research methods in tourism: Quantitative and qualitative approaches (pp. 403-416). Edward Elgar Publishing.

Topuz, E. (2017). Tanzimat Sonrası Osmanlı'da Otelcilik Teşebbüsleri ve Osmanlı Oteller Kumpanyası. IWACT International West Asia Congress of Tourism Research, June, 2017, Van.

Towner, J. (1995). What is tourism's history?. Tourism Management, 16 (5), 339-343.

Varlık, N. (2015). Plague and Empire in the Early Modern Mediterranean World: The Ottoman Experience, 1347-1600. Cambridge : Cambridge University Press.

Weed, M. (2020). The role of the interface of sport and tourism in the response to the COVID-19 pandemic. Journal of Sport \& Tourism, 1-14.

Welford, M. (2018). Geographies of Plague Pandemics: The Spatial-Temporal Behavior of Plague to the Modern Day. Routledge.

Wilks, J., Pendergast, D., and Leggatt, P. (Eds.). (2005). Tourism in turbulent times. Oxford: Elsevier.

World Bank. (2020). Air transport, passengers carried. https://data.worldbank.org/indicator/is.air.psgr. Accessed 04 April 2020.

World Health Organization (2020). Coronavirus disease (COVID-2019) situation reports. https://www.who.int/emergencies/diseases/novelcoronavirus-2019/situation-reports/.

Accessed 10. July 2020.

Wu, T., Perrings, C., Kinzig, A., Collins, J. P., Minteer, B. A., and Daszak, P. (2017). Economic growth, urbanization, globalization, and the risks of emerging infectious diseases in China: a review. Ambio, 46(1), 18-29.

Yakartepe, E. Ç., and Binan, C. (2011). İstanbul'un Modernleşme Dönemi Otelleri (18401914). Megaron, 6(2). 
Yan, Q., and Zhang, H. Q. (2012). Evaluation of the economic effectiveness of public tourism coupons in China in 2009 - A corrected DEA approach. Asia Pacific Journal of Tourism Research, 17(5), 534-550.

Yang, Y., Zhang, H., and Chen, X. (2020). Coronavirus pandemic and tourism: Dynamic stochastic general equilibrium modeling of infectious disease outbreak. Annals of Tourism Research, 83, 1-6.

Yenipınar, U., and Çapar, G. (2017). Tourist Guiding on The Silk Route: Turkey as a Crossroad Country. In R.Efe, R.Penkova, J.Wendt, K. Saparov and J.Berdenov (Eds.), Developments in Social Sciences (pp.391-402). St. Kliment Ohridski University Press, Sofia.

Y1lmaz, A., Yetgin, D., and Kozak, N. (2018). A hotel in Anatolia in the last period of the Ottoman Empire: Hotel Tadia (1892-1922). Tourism Management Perspectives, 26, $118-125$.

Yin, R. K. (2016). Qualitative research from start to finish. New York: Guilford Press.

Yüksel, A. (2010). Zamansız bir teşebbüs: I. Dünya Savaşı yıllarında Osmanlı İmparatorluğu'nda turizmi geliştirme gayretleri. Doğu Batı Düşünce Derneği, Yıl:13, Say1:52.

Yüksel, A. (2012). II. Abdulhamid döneminde bilimsel, kültürel ve turistik amaçlarla Osmanlı ülkesine gelen Almanlar. International Journal of Social Science, 5(5), 413-433.

\section{Author Biography}

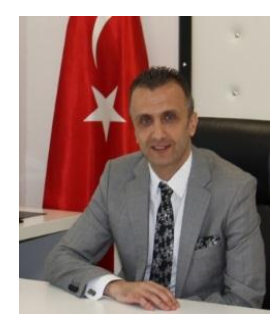

Dr. Burak Eryılmaz is an assistant professor in the Department of Tourism and Hotel Management in Vocational School of Social Sciences, in Amasya University, in Turkey. The author has master and doctorate degrees on tourism management. His main research interests are the marketing of the tourism, social media use in tourism as well as the historical practices in tourism. 